\title{
Positive Electrode Active Material for a Nonflammable Rocking Chair Type Lithium Secondary Battery with an Ambient Temperature Molten Salt Electrolyte

\author{
Koichi UI, Nobuyuki KOURA, Yasushi IDEMOTO* and Kazutaka IIZUKA
} \\ Received October 21, 1996 ; Accepted November 2C, 1996
}

\section{INTRODUCTION}

Ambient temperature molten salts, e.g., an $\mathrm{AlCl}_{3}$-1ethyl-3-methylimidazolium chloride(EMIC) system and an $\mathrm{AlCl}_{3}$-1-butylpyridinium chloride(BPC) system have been investigated for more than ten years as electrolytes for high energy density batteries ${ }^{1-3}$. Particularly, since an $\mathrm{AlCl}_{3}$-EMIC melt has a wide electrochemical window and is nonflammable, it is being considered as a nonflammable electrolyte for the $\mathrm{Li}$ secondary battery.

In a previous paper ${ }^{4}$, $\mathrm{Li}$ metal was added to the $\mathrm{LiCl}$ saturated $\mathrm{AlCl}_{3}$-EMIC melt $\left(50 \mathrm{~mol} \%<\mathrm{AlCl}_{3}\right)$ in order to completely remove $\mathrm{Al}_{2} \mathrm{Cl}_{7}$ that remained in the melt. As a result, $\mathrm{Al}$ was not deposited during cathodic polarization, and the electrochemical window of the melt was ca. $4.4 \mathrm{~V}$. When an $\mathrm{Al}$ foil was used as the negative substrate, $\mathrm{Li}$ was deposited on the substrate within the electrochemical window. Furthermore, since $c a$. $280 \mathrm{Ah} / \mathrm{kg}$ of discharge capacity was obtained in the potential plateau range of about $-1.5 \mathrm{~V}$ vs. $\mathrm{Al}$ at $0.4 \mathrm{~mA} / \mathrm{cm}^{2}$, it was found that an $\mathrm{Li}-\mathrm{Al}$ alloy could perform as the negative electrode active material.

The positive active material should then be investigated to evaluate this molten salt as the electrolyte for the rocking chair type Li secondary battery. In this study, several intercalation compounds, $\mathrm{LiCoO}_{2}, \mathrm{LiNiO}_{2}$,

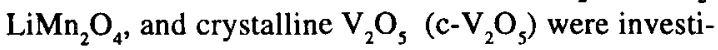
gated for the positive electrode active material.

\section{EXPERIMENTAL}

Melts were made by slowly adding anhydrous $\mathrm{AlCl}_{3}$ to EMIC (Tokyo Kasei Kogyo Co., Ltd,) with stirring until the desired molar ratio was obtained. The melts were purified by the $\mathrm{Al}$ substitution method ${ }^{3)}$. Anhydrous $\mathrm{LiCl}$ was dried under vacuum at $200^{\circ} \mathrm{C}$ for one week. On the basis of the calculated concentration of $\mathrm{Al}_{2} \mathrm{Cl}_{7}$, a $10 \sim$ $20 \%$ molar excess of $\mathrm{LiCl}$ was added to the $\mathrm{AlCl}_{3}$-EMIC melt. The melt was stirred overnight at $50^{\circ} \mathrm{C}$. Further-

Department of Industrial Chemistry, Faculty of Science and Technology, Tokyo University of Science, (2641 Yamazaki, Noda, Chiba, 278, Japan)

Key Words : Li secondary cell, Metal intercalation compound, Nonflammable electrolyte, Rocking chair type more, $\mathrm{Li}$ metal was added to the melt in order to reduce $\mathrm{Al}_{2} \mathrm{Cl}_{7}^{-}$that remained in the melt to $\mathrm{Al}$ and $\mathrm{AlCl}_{4}$ - The melt was used as the electrolyte after standing for $24 \mathrm{~h}$. Commercial c- $\mathrm{V}_{2} \mathrm{O}_{5}$ and $\mathrm{LiCoO}_{2}$ were used, and $\mathrm{LiMn}_{2} \mathrm{O}_{4}$ and $\mathrm{LiNiO}_{2}$ were prepared by conventional methods as the positive electrode active material. The working electrode was prepared by pressing $20.0 \mathrm{mg}$ of the mixtures of the active materials, $10.0 \mathrm{mg}$ acetylene black (AB), $10.0 \mathrm{mg}$ artificial graphite (AG), and $13.0 \mathrm{mg}$ polytetrafluoroethylene (PTFE) onto a current collector (Mo mesh: $1.0 \mathrm{~cm}^{2}$ ) . A $99.99 \% \mathrm{Al}$ wire $(\phi 2 \mathrm{~mm}) \mathrm{im}$ mersed in the $66.7 \mathrm{~mol} \% \mathrm{AlCl}_{3}-33.3 \mathrm{~mol} \%$ EMIC melt in a pyrex tube ( $\phi 10 \mathrm{~mm}$ ) separated by a G4 glass frit was used as the reference electrode. $\mathrm{Li}-\mathrm{Al}$ alloy was used as the negative electrode. The alloy was made by an electrolytic reduction method in the same melt by using an Al foil substrate (thickness $90 \mu \mathrm{m}, 8.0 \mathrm{~cm}^{2}$ ).

Fifty mg sample powders crushed into a particle size of several $\mu \mathrm{m}$ were immersed in an $\mathrm{LiCl}$ saturated $64.0 \mathrm{~mol} \% \mathrm{AlCl}_{3}-36.0 \mathrm{~mol} \% \mathrm{EMIC}\left(50.0 \mathrm{~mol} \% \mathrm{AlCl}_{3}\right.$ $28.1 \mathrm{~mol} \%$ EMIC-21.9mol\% LiCl) melt of $15 \mathrm{~m} \ell$ for 20 days to determine the solubility ${ }^{6}$. The dissolved metal ion was measured by ICP (Seiko electron SPS-7000).

The experiments were carried out in a glove box with a dry $\mathrm{N}_{2}$ atmosphere.

\section{RESULTS and DISCUSSION}

The $\mathrm{LiCl}$ saturated melt must have a carrier ion to function as a battery electrolyte. The constant resistance discharge test was examined using $\mathrm{c}-\mathrm{V}_{2} \mathrm{O}_{5}$ as the positive electrode and an $\mathrm{Li}-\mathrm{Al}$ alloy as the negative electrode (Fig. 1). The open-circuit voltage indicated $3.2 \mathrm{~V}$. It was confirmed that the $\mathrm{LiCl}$ saturated melt functions as the battery electrolyte and that the $\mathrm{Li}-\mathrm{Al} / \mathrm{LiCl}$ saturated $\mathrm{AlCl}_{3}-\mathrm{EMIC}$ melt/c- $\mathrm{V}_{2} \mathrm{O}_{5}$ cell operates.

Next, a charge-discharge test was carried out at a constant current using several intercalation compounds, i.e., $\mathrm{LiCoO}_{2}, \mathrm{LiNiO}_{2}, \mathrm{LiMn}_{2} \mathrm{O}_{4}$, and $\mathrm{c}-\mathrm{V}_{2} \mathrm{O}_{5}$ as the positive electrode active material (Fig. 2). The rest potential of $\mathrm{Li}-\mathrm{Al}$ alloy is $-1.7 \mathrm{~V} \mathrm{vs}$. $\mathrm{Al}^{4}$ ). The $\mathrm{LiCoO}_{2}$ (Fig. 2a) showed a charge capacity of $135 \mathrm{Ah} / \mathrm{kg}$ and the discharge capacity of $124 \mathrm{Ah} / \mathrm{kg}$ at a discharge potential of $1.9 \sim 0.9 \mathrm{~V}$ 
vs. Al. The charge-discharge efficiency was $91.9 \%$. The $\mathrm{LiNiO}_{2}$ (Fig. 2b) showed a 135Ah/kg charge capacity, a $100 \mathrm{Ah} / \mathrm{kg}$ discharge capacity at $1.8 \sim 0.8 \mathrm{~V}$ vs. $\mathrm{Al}$, and 74.0\% efficiency. The $\mathrm{LiMn}_{2} \mathrm{O}_{4}$ (Fig. 2c) showed a $140 \mathrm{Ah} / \mathrm{kg}$ charge capacity, a $92 \mathrm{Al} / \mathrm{kg}$ discharge capacity at $2.0 \sim 1.0 \mathrm{~V}$ vs. $\mathrm{Al}$, and $65.7 \%$ efficiency. The $\mathrm{c}-\mathrm{V}_{2} \mathrm{O}_{5}$ (Fig. 2d) showed a 146Ah/kg charge capacity, a 146Ah/ $\mathrm{kg}$ discharge capacity at $1.4 \sim 0.4 \mathrm{~V}$ vs. Al, and $100 \%$ efficiency. From these results, it was suggested that the charge-discharge is possible within the electrochemical window $(2.3 \sim-2.1 \mathrm{~V} \text { vs. } \mathrm{Al})^{4)}$.

The graphite compound used as a conductive additive is a typical intercalation compound and it can be intercalated by cations and anions ${ }^{7}$. So, charge-discharge tests for $A G$ (e) and $A B$ (f) were also performed. The capacities for $A G$ and $A B$ were $c a .2$ and $4 \mathrm{Ah} / \mathrm{kg}$, respectively. It was confirmed that these (e and $f$ ) capacities correspond to only $1 \sim 3 \%$ of $a, b, c$, and $d$.

On the other hand, the active material should be stable in the melt in order to lengthen the cycle life. The solubility of the positive electrode active materials for $\mathrm{Li} \mathrm{sec}$ ondary battery in the melt was investigated (Table 1). The solubility of the compounds was less than $0.1 \mathrm{wt} \%$. It was confirmed that the compounds are chemically stable in the melt.

The possibility of the rocking chair type Li secondary battery operating at room temperature with the $\mathrm{LiCl}$ saturated melt electrolyte was suggested using the above compounds as the positive electrode active material.

This work was partly supported by the Light Metal Educational Foundation.

We sincerely thank Mr. Moriyasu Wada and Mr. Shintaro Suzuki at Toshiba Battery Co., Ltd. for providing the amorphous $\mathrm{V}_{2} \mathrm{O}_{5}$, acetylene black, and artificial graphite. We also thank Mr. Yasushi Mukai and Mr. Koji Mori of Tokyo University of Science for preparing the $\mathrm{LiNiO}_{2}$ and $\mathrm{LiMn}_{2} \mathrm{O}_{4}$.

\section{References}

1)C. J. Dymek, Jr., G. F. Reynolds, and J. S. Wilkes, J. Electrochem. Soc., 134, 1658(1987).

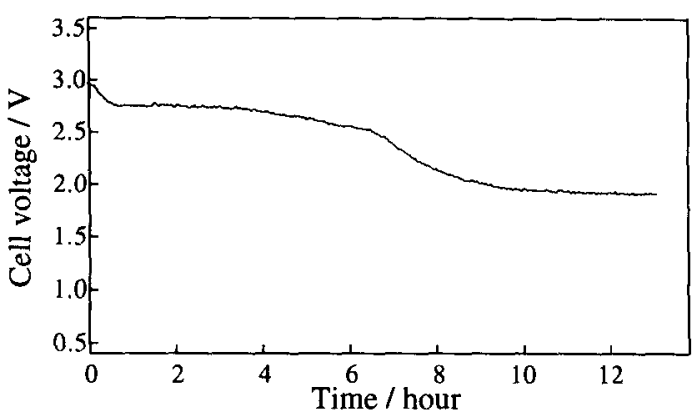

Fig. 1 Discharge curves for an $\mathrm{Li}-\mathrm{Al} / \mathrm{LiCl}$ saturated $64.0 \mathrm{~mol} \% \mathrm{AlCl}_{3}-36.0 \mathrm{~mol} \% \mathrm{EMIC} / \mathrm{c}-\mathrm{V}_{2} \mathrm{O}_{5}$ cell at $25^{\circ} \mathrm{C}$.

Constant resistance : $9.9 \mathrm{k} \Omega$.

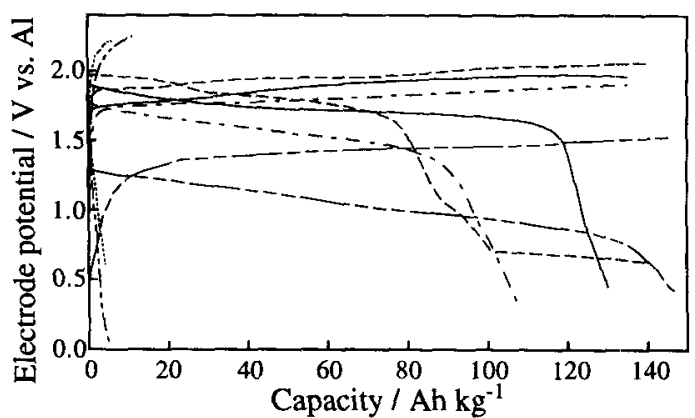

Fig. 2 First charge and discharge curves for an $\mathrm{Li}-\mathrm{Al} /$ $\mathrm{LiCl}$ saturated $64.0 \mathrm{~mol} \% \mathrm{AlCl}_{3}-36.0 \mathrm{~mol} \% \mathrm{EMIC} / \mathrm{metal}$ intercalation compounds cell at $25^{\circ} \mathrm{C}$.

- $: \mathrm{LiCoO}_{2}$ (a), --- : $\mathrm{LiNiO}_{2}$ (b), $\cdots \cdot \mathrm{LiMn}_{2} \mathrm{O}_{4}$ (c), $\cdots-: \mathrm{c}^{-} \mathrm{V}_{2} \mathrm{O}_{5}(\mathrm{~d}), \cdots \cdots \cdots: \mathrm{AG}(\mathrm{e})$, and $\cdots-: \mathrm{AB}(\mathrm{f})$. Current density: $0.2 \mathrm{~mA} \cdot \mathrm{cm}^{-2}$.

2)N. Koura, H. Ejiri, and K. Takeishi, J. Electrochem. Soc., 140, 602 (1993).

3)Y. S. Fung and S. M. Chau, J. Appl. Electrochem., 23, 346(1993).

4)N. Koura and K. Ui, Light Metals, Submitted for publication.

5)S. Takahashi and N. Koura, J. Electroanal. Chem., 188, 245 (1985).

6)N. Takami and N. Koura, Denki kagaku, 56, 28 (1988).

7)M. Dohzono, H. Katsuki, and M. Egashira, $J$. Electrochem. Soc., 136, 1255 (1989).

Table 1 Solubility of metal intercalation compounds at $25^{\circ} \mathrm{C}$ in an $\mathrm{LiCl}$ saturated $64.0 \mathrm{~mol} \% \mathrm{AlCl}_{3}-36.0 \mathrm{~mol} \% \mathrm{EMIC}$ melt electrolyte.

\begin{tabular}{ccccccc}
\hline & $\mathrm{LiCoO}$ & $\mathrm{LiNiO}_{2}$ & $\mathrm{LiMn}_{2} \mathrm{O}_{4}$ & $\mathrm{a}-\mathrm{V}_{2} \mathrm{O}_{5}$ & $\mathrm{c}-\mathrm{V}_{2} \mathrm{O}_{5}$ \\
\hline Solubility $/ \mathrm{mg} \cdot \ell^{-1}$ & 0.336 & 0.185 & 0.3921 & 2.972 & 4.372 \\
\hline $\mathrm{c}-\mathrm{V}_{2} \mathrm{O}_{5}$ : crystalline $\mathrm{V}_{2} \mathrm{O}_{5}, \mathrm{a}-\mathrm{V}_{2} \mathrm{O}_{5}:$ andorphous $\mathrm{V}_{2} \mathrm{O}_{5}$ & & & &
\end{tabular}

